\title{
Evaluation of inner teat morphology by using high-resolution ultrasound: Changes due to milking and establishment of measurement traits of the distal teat canal
}

\author{
L. M. Martin, ${ }^{+} \dagger^{1}$ C. Stöcker, ${ }^{*}$ H. Sauerwein, ${ }^{*}$ W. Büscher, $\ddagger$ and U. Müller ${ }^{*} \dagger$ \\ *Institute of Animal Science, Department of Physiology and Hygiene, \\ †Center of Integrated Dairy Research, and \\ łInstitute of Agricultural Engineering, Department of Livestock Technology, University of Bonn, Bonn 53115, Germany
}

\begin{abstract}
The teat canal is important in the defense against invading pathogens, but its functional features can be impeded by the milking process. The objective of our study was to compare teat morphology before and after a standard milking procedure using high-resolution ultrasonography. Tissue changes were determined by measuring inner traits of teat morphology: teat width, teat end width, teat cistern width, diameter of the lower and upper teat wall, teat canal length, and teat canal diameter. Additionally, 3 traits describing the distal teat canal and its external orifice were established: diameter of the distal teat canal orifice, distal teat canal perimeter, and distal teat canal surface. In the first trial, we verified the repeatability of scanning over time with a mixed model. During the second trial, significant changes after milking were observed for all measured traits of teat morphology except teat end width. The traits from the distal teat canal and its orifice were remarkably changed by milking: distal teat canal orifice, $+28.9 \%$; distal teat canal perimeter, $+25.0 \%$; and distal teat canal surface, $+41.5 \%$. Comparing multiparous versus primiparous cows, higher values of teat width, teat end width, and teat canal length were observed in the older animals. Testing the effect of milk yield on teat dimensions, cows with milk yields $>11.0 \mathrm{~kg}$ /afternoon milking were found to have larger teat widths, teat end widths, and cistern widths before attachment of the cluster. Furthermore, we observed associations of inner teat morphology toward bacterial counts in the appropriate milk. Regarding this udder health-related parameter especially, the newly established traits showed a connection. Teats in which milk showed bacterial growth had larger distal teat canal perimeters and distal teat canal surfaces. High-
\end{abstract}

Received January 26, 2018.

Accepted May 7, 2018.

${ }^{1}$ Corresponding author: Lisett.Martin@uni-bonn.de resolution ultrasonographic scanning of dairy teats allowed a detailed visualization of the inner morphology. The applied procedure can therefore serve as a useful tool for comparison and evaluation of different milking techniques by analyzing the resulting changes of the morphological traits. The thorough description of teat tissue can also be applied for drawing conclusions on the status of the teat canal's physical and mechanical defense function.

Key words: ultrasonographic scanning, teat canal, udder health, teat morphology

\section{INTRODUCTION}

Maintaining a healthy mammary gland in dairy cows is indispensable for good production performance and the animals' well-being. The inner morphology of the lactating bovine teat and its modifications during the milking procedure play an important role in the defense against mastitis. The teat canal is highly specialized in its function of preventing leakage of milk and entry of microorganisms. Complex anatomical and immunological defense mechanisms are known (Krömker, 2014). A smooth muscle sphincter allows opening and closure of the distal teat canal orifice during the milking process; this sphincter is considered to form the first physical and mechanical barrier against invasion of bacteria by closing the most important portal of entry for pathogens into the mammary gland (O'Shea, 1987). Consequently, teat canal penetrability is an important aspect of udder health and therefore affects health management strategies on dairy farms. Teat morphology differs among breeds (Klein et al., 2005; Bobić et al., 2014), between cows, and quarters within cows (Zwertvaegher et al., 2012 ) and is furthermore influenced by the milking procedure (Gleeson et al., 2004; Guarín and Ruegg, 2016). Machine milking may induce changes in teat dimensions as well as in the teat tissue, such as congestion and hyperkeratosis (Neijenhuis et al., 2001b). A vacuum applied to the teat to open the teat canal makes the 
milk available but also leads to accumulation of blood and lymph in the teat tissue (Hamann et al., 1993). The magnitude of change in the teat canal is influenced by the milking machine settings such as machine-on time, applied vacuum level, or type of teat cup liners (Hamann et al., 1993; Hillerton et al., 2000; Paulrud et al., 2005; Penry et al., 2017). Various studies have been conducted to analyze the morphology of the bovine teat and its changes due to milk removal. External studies used a 2-dimensional vision-based measuring technique (Zwertvaegher et al., 2013) or a translucent measuring ruler (Guarín and Ruegg, 2016). For investigation of the teats' inner morphology ultrasound has been used, and a variety of traits are known to be useful for measurements in ultrasonographic studies of the bovine teat (Neijenhuis et al., 2001a; Weiss et al., 2004; Szencziová et al., 2013; Bobić et al., 2014; Fasulkov et al., 2014; Strapák et al., 2017; Wieland et al., 2018). However, hardly any studies have focused on the teat tip area. As the teat canal is considered to be the main infectious path for pathogens, its unimpeded functionality is essential for sufficient udder health. This motivated us to particularly investigate the morphological structure of the distal teat canal and its orifice via ultrasonographic scanning, thereby establishing additional measurement traits describing this delicate area. Ultrasonographic investigations are easy to apply and noninvasive and thus allow for visualizing the teats' internal structure and their morphological changes during milking. However, the morphological dimensions of the teat canal are very small, and scans of excellent image quality together with appropriate software are required for ensuring high accuracy and reliability, which in turn allow for identification of influencing factors such as the milking process or peculiarities of individual cows rather than interpreting measurement errors. Therefore, the objective of our study was to visualize and analyze the inner teat morphology in a detailed way by applying a high-resolution probe of $18 \mathrm{MHz}$ and establishing new measurement traits. Furthermore, our aim was to describe the changes in the teats' overall morphology caused by milking and their associations with other variables of the individual cow, such as parity, and particular aspects of milkability and udder health.

\section{MATERIALS AND METHODS}

\section{Animals and Sampling}

The experiments were carried out at the Frankenforst research station of the University of Bonn (Königswinter, Germany). The experimental procedures (June 2016 to October 2017) performed in this study were ap- proved by the relevant authority (Landesamt für Natur-, Umwelt- und Verbraucherschutz Nordrhein-Westfalen, Recklinghausen; 84-02.04.2016.A047) and were in strict accordance with the German animal protection law.

The Holstein dairy herd $(\mathrm{n}=72)$ was loose-housed in a 2-row open freestall barn with cubicles and a concrete floor. All animals were fed with a mixed ration and additional concentrate depending on the individual performance. The cows were milked twice per day at 0530 and $1630 \mathrm{~h}$. Milking was performed in a double-4 in-line milking parlor (GEA Farm Technologies GmbH, Bönen, Germany) at a pulsation rate of 62 pulses/min, a pulsation ratio of 64:36, and a vacuum level of $40 \mathrm{kPa}$. The milk pipelines were placed below cow standing level; thus, the milk was transported to the tank without lifting. The clusters were removed automatically when total milk flow decreased below $0.3 \mathrm{~kg} / \mathrm{min}$. Premilking treatment consisted of udder cleaning with a wet paper towel and stripping of the first milk squirts in addition to mechanical prestimulation (300 pulses/min during the first $30 \mathrm{~s}$ ). Milk yield, milking duration, and peak flow rate were recorded at the level of the udder by Metatron C21 (GEA Farm Technologies GmbH).

For monitoring bacterial contents and SCC, we collected aseptic milk samples at the quarter level between the routine premilking treatment and the ultrasonographic scanning. Before sampling, the first strippings of milk from each quarter were discarded; teat ends were then disinfected with $70 \%$ alcohol and allowed to dry. After that, milk samples were taken into sterile vials and transported refrigerated to a commercial laboratory.

\section{Bacteriological Culture and SCC}

Bacteriological analyses were carried out according to the recommendations of the German Veterinary Society regarding the isolation and identification of mastitis pathogens (DVG, 2009). Milk samples were plated $(10 \mu \mathrm{L})$ on blood agar (Oxoid, Wesel, Germany), incubated $\left(37^{\circ} \mathrm{C}\right)$, and optically evaluated after 24 and $48 \mathrm{~h}$ for overall extent of bacterial growth. Accordingly, the quarters were classified either as group 0 (no growth of pathogens detectable) or group 1 (growth of pathogens detectable). Pathogens were then cultivated in pure culture on plate count (VWR, Darmstadt, Germany) or blood agar and identified via matrix-assisted laser desorption/ionization time-of-flight MS by the Chemical and Veterinary Investigation Office (CVUA, Stuttgart, Germany). Somatic cell counts in the quarter milk samples were quantified by using an automated cell counter (DCC cell counter; DeLaval GmbH, Glinde, Germany). For the procedure, $60 \mu \mathrm{L}$ of milk sample 
was aspirated into a small cassette. A DNA-specific fluorescent reagent bound to the SCC nuclei, which were then counted by an integrated digital camera. The SCC values are given as base 10 logarithms.

\section{Experimental Design and Ultrasonographic Scanning}

We used a MyLab Five Vet scanner with a multifrequency $(6-18 \mathrm{MHz})$ linear array probe (Esaote Biomedica $\mathrm{GmbH}$, Cologne, Germany) to record ultrasound images of 50 (trial 1) and 138 (trial 2) teats. The trials are described in detail below. The scans were performed on the longitudinal cross-section of the left and right front teats at the afternoon milking with B-mode 18 $\mathrm{MHz}$. To avoid deformation of the teat image by direct contact of the probe, we used a plastic cup $(7 \times 5 \times$ $12 \mathrm{~cm}$ ) filled with lukewarm tap water to immerse the teat. Lateral to the teat the probe was held against the cup. To ensure an adequate contact between probe and cup, we used ultrasonic gel (Aquasonic 100, Parker Laboratories Inc., Fairfield, NJ). Scans before milking (T0) were carried out after routine teat preparation and collection of milk samples to ensure a sufficiently filled teat cistern. Scans after milking (T1) were conducted immediately after milking, not later than 3 min after automatic cluster removal. The real-time scanning was observed on the screen of the scanning device. Taking the longitudinally folded cylinder-shaped structure of the teat canal (Paulrud, 2005) into account, we aimed to conduct each scan at the respective point of widest diameter. Therefore, the probe was slowly moved on the plastic cup along the horizontal line of the teat, visualizing the teat canal in its overall morphology. The scanning procedure was performed until the resulting picture showed a sufficient quality (visibility of the whole teat at least $10 \mathrm{~mm}$ proximal to the Furstenberg's rosette, adequate sharpness, and good visibility of the ideally widest point of the teat canal diameter). As soon as the teat morphology appeared in adequate sharpness, the "freeze" button was pushed. The scanning device makes the previous 400 images available, and thus we were able to select the respective picture with the highest quality regardless of whether the button was pressed at the exact second. The resulting pictures were stored in the internal memory of the scanning device. After the milking time, the pictures were transferred to a computer via USB device. Measurements were conducted at a computer using MyLabDesk software (version 10.0, Esaote Biomedica $\mathrm{GmbH}$ ) with an accuracy of $0.1 \mathrm{~mm}$ and were all conducted by the same person. We assessed 10 different morphological characteristics of the teat as shown in Figure 1. Teat width (TW; in $\mathrm{mm}$ ) was measured orthogonally to the teat canal $10 \mathrm{~mm}$ proximal to the rosette of Furstenberg. The diameter of the teat on the same orthogonal axis at the point of the rosette of Furstenberg was measured as teat end width (TEW; in mm). Diameters of the teat cistern (TCW; in $\mathrm{mm}$ ) and the lower (TWT1; in $\mathrm{mm}$ ) and upper (TWT2; in mm) teat wall were measured at the vertical line of TW. The length of the teat canal (TCL; in $\mathrm{mm}$ ) was measured from the rosette of Furstenberg up to the distal end of the teat canal. The resulting axis of the teat canal served as a direction for measurements of teat dimension as mentioned before. The diameter of the teat canal (TCD) was measured $5 \mathrm{~mm}$ distal to the rosette of Furstenberg. In addition to these 7 traits of teat morphology that have been applied similarly in previous studies (compare Neijenhuis et al., 2001a; Strapák et al., 2017), 3 traits focusing on the area of the distal teat canal were assessed. At the distal end of the teat canal we measured the width of the teat canal's orifice (TOR; in $\mathrm{mm}$ ). The perimeter of the distal teat canal (DTCp; in $\mathrm{mm}$ ) was measured starting at $5 \mathrm{~mm}$ distal to the rosette of Furstenberg at the measurement point of TCD up to the distal orifice (TOR). The perimeter was defined by manually setting measuring points hemming the hyperechoic area of the distal teat canal using the feature for determining perimeters of the MyLabDesk software. The measurement software displayed the distal teat canal's marked perimeter in millimeters (DTCp) and then calculated the surrounding surface (DTCs; in $\mathrm{mm}^{2}$ ).

Trial 1 was performed to characterize the repeatability of the scans. Twenty-five randomly selected cows (average lactation number $3.0 \pm 1.7$ ) from the herd were assigned to 3 sequentially repeated ultrasonographic scans at weekly intervals. At each scanning date, ultrasonographic scans of every front teat - 1 scan before (T0) and 1 scan after (T1) milking - were done to evaluate the effects of the milking process. In total, 300 ultrasonographic scans from 50 teats were recorded.

Trial 2 was conducted to compare teat morphology before and after milking, aiming for evaluation of the effects of the milking process. Scans were done in 69 cows (average lactation number $2.4 \pm 1.4$ ) of the herd and included 2 ultrasonographic scans of every front teat [i.e., before (T0) and after (T1) milking]. In total, 276 ultrasonographic scans from 138 teats were recorded.

All cows included in both trials had to be free of clinical mastitis and udder abnormalities. Number of lactations, milk yields, and milking traits of the experimental cows are shown in Table 1.

\section{Statistical Analyses}

The obtained data were analyzed using SPSS Statistics (version 24.0; SPSS Inc., Chicago, IL). Data were 


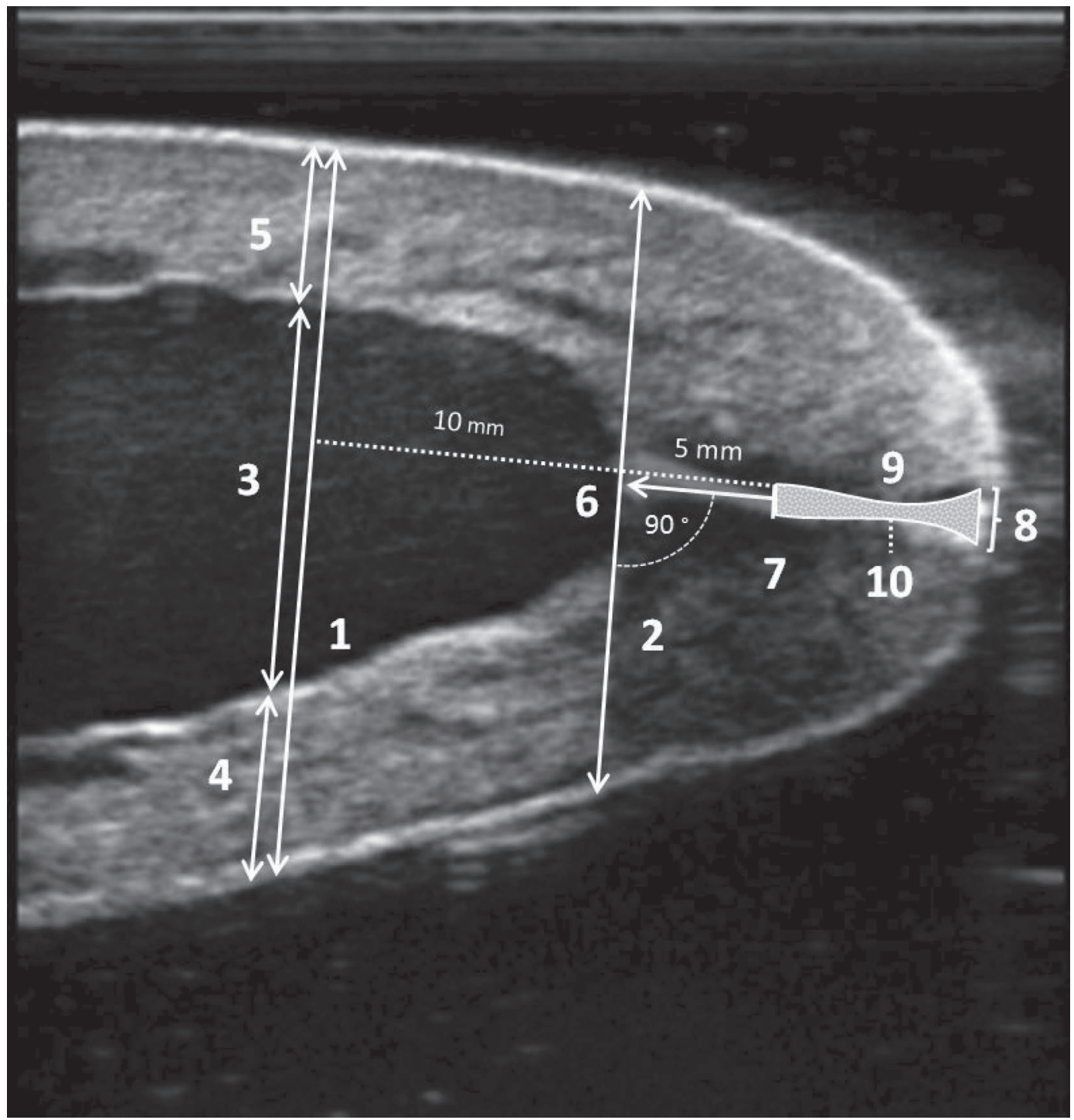

Figure 1. Measurement positions of the traits of inner teat morphology. 1 = width $(\mathrm{mm})$ of the teat $10 \mathrm{~mm}$ proximal to the rosette of Furstenberg; $2=$ width $(\mathrm{mm})$ of the teat end at the rosette of Furstenberg; $3=$ width $(\mathrm{mm})$ of the teat cistern $10 \mathrm{~mm}$ proximal to the rosette of Furstenberg; $4=$ diameter $(\mathrm{mm})$ of the lower teat wall $10 \mathrm{~mm}$ proximal to the rosette of Furstenberg; $5=$ diameter (mm) of the upper teat wall $10 \mathrm{~mm}$ proximal to the rosette of Furstenberg; $6=$ length of the teat canal $(\mathrm{mm}) ; 7=$ diameter $(\mathrm{mm})$ of the teat canal $5 \mathrm{~mm}$ distal to the rosette of Furstenberg; $8=$ width $(\mathrm{mm})$ of the teat canal distal orifice; $9=$ perimeter $(\mathrm{mm})$ of the distal teat canal beginning $5 \mathrm{~mm}$ distal to the rosette of Furstenberg until the distal orifice; $10=\operatorname{surface}\left(\mathrm{mm}^{2}\right)$ of the distal teat canal referring to the perimeter of the distal teat canal.

Table 1. Descriptive statistics of lactation number, milk yield, and milkability traits ${ }^{1}$ from the experimental cows

\begin{tabular}{|c|c|c|c|c|c|c|c|c|}
\hline Trait & \multicolumn{4}{|c|}{ Trial $1(\mathrm{n}=25)$} & \multicolumn{4}{|c|}{ Trial $2(\mathrm{n}=69)$} \\
\hline Lactation no. & 3.0 & 1.7 & 1 & 8 & 2.4 & 1.4 & 1 & 7 \\
\hline Milk yield (kg) & 14.7 & 4.9 & 8.2 & 22.6 & 12.3 & 4.8 & 3.4 & 21.8 \\
\hline Milking duration (min) & 6.27 & 1.6 & 4.9 & 9.2 & 5.8 & 2.0 & 2.6 & 12.9 \\
\hline Highest milk flow $(\mathrm{kg} / \mathrm{min})$ & 4.28 & 1.09 & 2.23 & 6.09 & 4.23 & 1.22 & 1.58 & 7.11 \\
\hline
\end{tabular}

\footnotetext{
${ }^{1}$ As assessed during the afternoon milking $(1630 \mathrm{~h})$.
} 
tested for normal distribution using the Shapiro-Wilk test. Variance homogeneity was checked with Levene's test $(P>0.10)$. During trial 1 , teat scans of the same 25 cows before and after the afternoon milking were done in weekly intervals across 3 wk to characterize the repeatability of teat scanning of the various traits from measurements over days. Cow was considered as the experimental unit, and linear mixed models were fitted to analyze the effect of time on the measured traits. Dates of measurements were included as fixed effects, and cow was included as a random effect. In addition, the standard error of the difference between means (SED) of the 3 measuring days was calculated to verify the effect of time. To provide the relation of the SED to the total mean for each trait, percentage values were calculated with reference to Neijenhuis et al. (2001a) as follows:

$$
\%=(\mathrm{SED} \text { trait } / \text { total mean }) \times 100 \text {. }
$$

In trial 2 , scans of the front teats $(\mathrm{n}=138)$ during the exact milking time (T0, T1) were used to assess the milking-related changes in teat morphology and their potential associations with parity as well as particular aspects of milking characteristics and udder health. The experimental unit during these analyses was the individual teat. Taking variance homogeneity into account, we performed a paired Student's $t$-test between the recorded values of each of the measured traits at T0 and T1 milking to determine their changes during milking. We used Student's $t$-tests to compare the subgroups of the experimental animals that were formed according to threshold values for different traits (multiparous vs. primiparous, milk yield $>$ or $<11.0 \mathrm{~kg}$, peak flow rate $>$ or $<4.0 \mathrm{~kg} / \mathrm{min}$; both on udder level). At the teat level, subgroups were formed according to the microbiology results of 138 quarter milk samples (i.e., with or without bacterial growth in the appropriate milk). For estimation of variance, multivariate ANOVA models were built. Measurements of teat traits at T0 and T1 and respective values of differences in the measured values in comparison of the time points were put into the model as dependent variables. Cow and lactation number (multiparous vs. primiparous) were included as fixed effects, and milk yield $(>$ or $<11.0 \mathrm{~kg}$ ) and peak flow rate $(>$ or $<4.0 \mathrm{~kg} / \mathrm{min})$ at the respective afternoon milking as well as bacteriological findings in the corresponding milk (with or without bacterial growth) served as covariates. We calculated Pearson's coefficients of correlation for determining potential associations between the different traits of teat morphology. Results were considered to be significant at $P<$ 0.05 . Values are given as means \pm standard deviation.

\section{RESULTS AND DISCUSSION}

During trial 1, aiming to characterize the repeatability, we conducted 300 scans ( 25 cows, 50 teats, 2 scans per teat immediately before and after milking). Of the 3,000 measurements theoretically possible (10 traits per scan), 2,898 measurements were actually done. To analyze the changes of teat morphology caused by the milking process (trial 2), we included 276 ultrasonographic scans in the data set (69 cows, 138 teats, 2 scans per teat immediately before and after milking). We were able to conduct 2,704 measurements of the theoretically possible 2,760. The total of 158 missing values was due to a few scans of inadequate quality, in which not all traits could be measured. The $2.7 \%$ unavailable data represents the high quality of the scans and a good applicability of the method.

\section{Repeatability of the Ultrasonographic Measurements}

During trial 1, the date of scanning was not associated with any of the variables assessed (average effect of time: $P=0.54$ ). Thus, all 10 variables of teat morphology were repeatable at least over 3 wk. Neijenhuis et al. (2001a) stated that differences between days are comparable with differences between duplicate measurements; therefore, and because of the intense nature of the scanning procedure, we renounced on duplicating scans. To analyze the mean differences in response to day of measurement, we provided the SED for each measured trait (Table 2). The mean difference of ultrasound measurements of the various teat parameters between days varied from $1.6 \%$ for TW after milking to $10.9 \%$ for DTCs before milking (Table 2). Differences between days measured by Neijenhuis et al. (2001a) ranged from $4.4 \%$ for TEW up to $19.9 \%$ for TCW. Based on our relatively small variation of means between days and the independence of time, it can be stated that the applied method was characterized by a good repeatability. Aiming to analyze teat morphology in greater detail, we established 3 additional measurement traits with focus on the distal teat canal. Repeatability of these traits was equal to that of the measurement traits already applied in ultrasound studies of lactating teats in the literature (Neijenhuis et al., 2001a). The utilization of a high-resolution scanning device in our trials showed that it could be applied easily and without stress for the animals due to the noninvasive nature of the technique. Furthermore, it was fairly easy for the user to operate. Precise measurements were enabled by a high image quality and were based on implementation of measurement software of high accuracy. The conduction of all image analyses 
Table 2. Differences in mean measurements of internal teat traits of the same 25 cows on 3 different days before (T0) and after (T1) milking (trial 1)

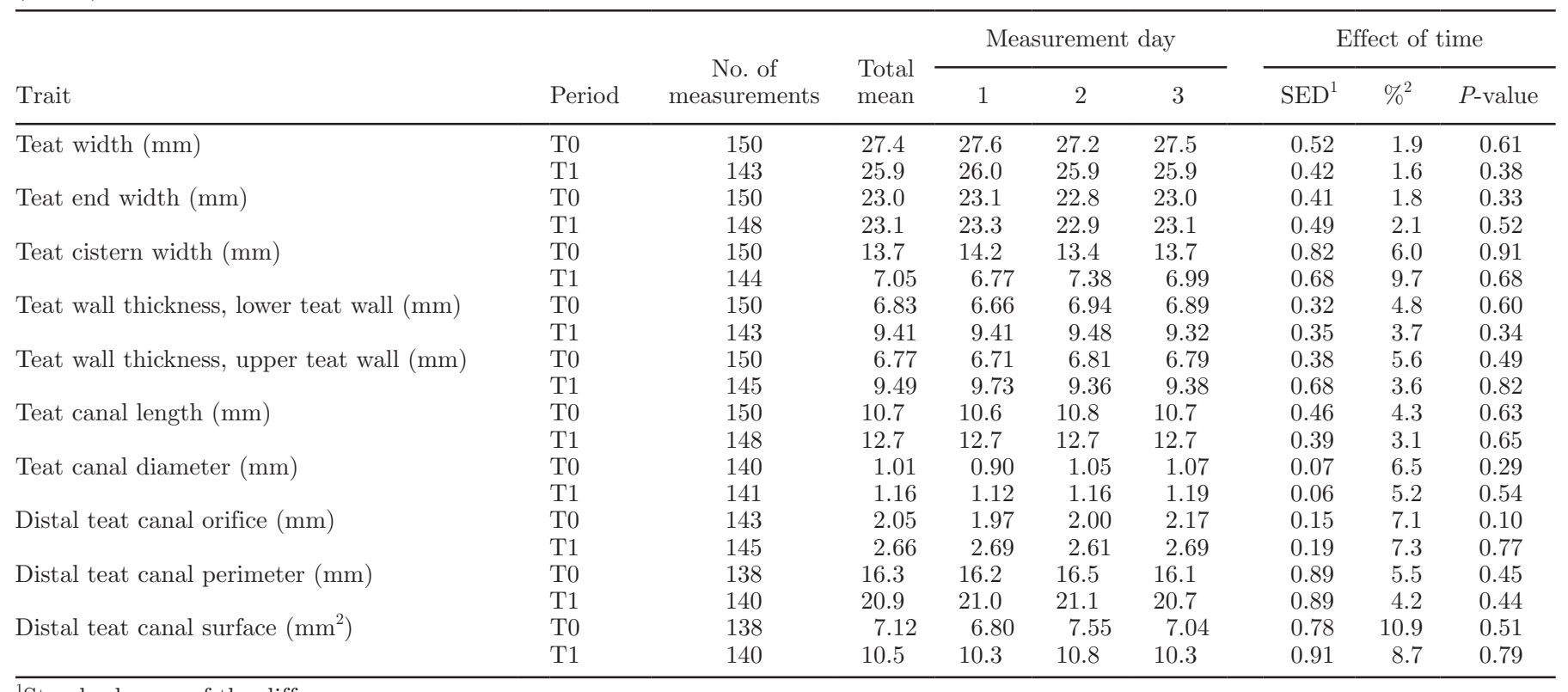

${ }^{1}$ Standard error of the difference.

${ }^{2}$ Calculated as (SED trait/total mean) $\times 100$.

through the same observer is emphasized by Wieland et al. (2018), mentioning the risk of decreased precision in estimates and power to detect coherences of interest when performing measurements by various observers.

\section{Changes of Teat Morphology During Milking}

Except for TEW, all traits were associated with the milking process $(P<0.001)$; that is, different values were obtained before and after milking, as shown in Table 3. In our study, TCW showed the highest relative changes after milking. Neijenhuis et al. (2001a) had similar findings, with an average decrease of $45.8 \%$ in cistern width. During the milking process the milk is withdrawn from the teat cistern, and the dimension of the teat walls increases as the cistern volume decreases. During the vacuum phase strain is generated in the teat tissue, which leads to a dilatation of blood vessels. Swelling of teat walls can be explained by the machine-induced accumulation of fluid (blood and lymph; Hamann et al., 1993). However, appropriate milking machine settings should provide pulsation characteristics that enable effective teat massage and venous flow, so the interstitial fluid can drain off when the liner compresses during the massage phase (IDF, 1987). Teat shape in its overall width was only slightly affected, which was in accordance with previous studies (Paulrud et al., 2005; Kuchler, 2011; Bobić et al., 2014). In our experiment, average change in TEW was about $0.15 \%$. Therefore we can conclude that the machine settings did not lead to an intense accruement of edema. Stretching in length of the teat tissue was due to the vacuum and the weight of the cluster attached to the teat. Strapák et al. (2017) had similar findings of a $20.5 \%$ average elongation of the teat canal in front teats. Even higher changes $(27 \%)$ were reported by Szencziová et al. (2013). Neijenhuis et al. (2001a) found less stretching of the teat canal of $12 \%$. These divergent outcomes might be explained by application of varying milking techniques and morphological variation of the experimental animals' teat tissue. Consequently, in our study general teat shape was much more affected in its length than in its width as a consequence of the milking procedure. Dimensions of teat width scaled down about an average of $6.07 \%$ and a maximum of $8.96 \%$ (for TW), whereas extension of TCL reached $19 \%$ on average, with a maximum of $49 \%$. The same effect of overall shape adjustment was observed by Neijenhuis et al. (2001a). Using a translucent measuring ruler, Guarín and Ruegg (2016) also found postmilking teats to be longer and narrower than premilking teats. Regarding the diameter of the teat canal, Strapák et al. (2017) found changes of $9 \%$ from $1.11 \mathrm{~mm}$ to $1.21 \mathrm{~mm}$, also based on measurements in Holstein cows' front teats. The higher extension of the average diameter recorded in our study may not be explained only by different milking machine settings or the varying initial condition of the study animals' morphological characteristics 
before milking. Variation in the software tools used to measure the scans probably also had an effect on the resulting values.

In addition to the classical teat canal traits, 3 innovative characteristics were established herein, describing the area of the distal teat canal and its external orifice in greater detail. Milk flow through the teat canal not only extended the diameter of the teat canal at $5 \mathrm{~mm}$ proximal to the rosette of Furstenberg (TCD) but also led to a widening $(P<0.001)$ of the orifice (TOR) as well as the perimeter (DTCp) and surface (DTCs) of the distal teat canal. To evaluate a standard operating procedure for ultrasound-based measurements of teat canal dimensions, Wieland et al. (2018) measured a related trait defined as the teat canal diameter at the distal end of the teat canal using a 5 - to $10-\mathrm{MHz}$ probe. Obtained data were of comparable scale $(2.42 \pm 0.43$ $\mathrm{mm})$.

Associations between the measured traits of teat morphology were identified by correlation analysis (Pearson). The DTCp and DTCs were correlated with TCL because measurement of both traits describing the distal teat canal started $5 \mathrm{~mm}$ distal to the rosette of Furstenberg. Therefore, higher values of DTCp and DTCs were observed with increasing length of the teat canal (DTCp: T0 $\mathrm{r}=0.91, \mathrm{~T} 1 \mathrm{r}=0.88$; DTCs: T0 $\mathrm{r}$ $=0.63, \mathrm{~T} 1 \mathrm{r}=0.57 ; P<0.01)$. Regarding the distal teat canal, we found correlations between all 3 newly established characteristics. A great distal orifice (TOR) was related to larger perimeter (DTCp) and surface (DTCs) of the distal teat canal (DTCp: T0 $\mathrm{r}=0.31$, T1 $\mathrm{r}=0.40$; DTCs: T0 $\mathrm{r}=0.59$, T1 $\mathrm{r}=0.69 ; P<$ 0.01). Positive correlations were also detected between TCL and the diameters of the teat walls (TWT1: T0 r $=0.0 .49$, T1 $\mathrm{r}=0.0 .33$; TWT2: T0 $\mathrm{r}=0.40, \mathrm{~T} 1 \mathrm{r}=$ $0.33 ; P<0.01)$. These findings are in accordance with
Weiss et al. (2004), who found a correlation of $\mathrm{r}=0.50$ $(P<0.001)$.

In this study we also analyzed the connection between animal-specific data (e.g., parity or traits related to udder health and milkability) and teat morphology. Milk yield was found to be connected to the inner morphology of the teat. For comparison of the experimental animals, we formed 2 groups among a threshold value of $11.0 \mathrm{~kg}$ of afternoon milk yield $(>11.0 \mathrm{~kg}, \mathrm{n}=36$; $<11.0 \mathrm{~kg}, \mathrm{n}=33)$. This value corresponds to the median afternoon milk yield of the cows $(11.0 \mathrm{~kg})$ and was used because milk yield data were not normally distributed. Cows with an afternoon milk yield $>11.0 \mathrm{~kg}$ had larger $(P=0.01)$ cistern $(14.5 \pm 3.07 \mathrm{~mm}$ compared with 13.0 $\pm 3.53 \mathrm{~mm}$ in lower yield cows) and teat width $(P=$ 0.001 ; TW $27.0 \pm 1.75 \mathrm{~mm}$ and TEW $23.0 \pm 1.56 \mathrm{~mm}$ compared with TW $26.3 \pm 2.20 \mathrm{~mm}$ and TEW $22.1 \pm$ $1.67 \mathrm{~mm}$ in lower yield cows) before attachment of the clusters due to the teats bulging with milk and showed a higher difference in the measured values in comparison of the time points. Consistent with the bigger milk volume removed in cows with $>11.0 \mathrm{~kg}$ milk yield, the differences in TW and TCW were higher $(P=0.005$ and 0.002 , respectively) than in cows with milk yields $<11.0 \mathrm{~kg}$. The TCW was reduced by $7.39 \pm 3.12 \mathrm{~mm}$ in cows with higher yields and by $5.69 \pm 2.92 \mathrm{~mm}$ in cows with lower yields in the course of removal of the milk. Bobić et al. (2014) also emphasized a slight connection $(\mathrm{r}=0.27, P<0.05)$ between dimensions of the teat cistern and milk yield in front teats. Connections between the measured values of TW and milk yield could not be verified by Weiss et al. (2004). This might be explained by a higher average milk yield during our experiment $(27.1 \pm 9.98 \mathrm{~kg})$ compared with the milk production of cows enrolled by Weiss et al. (2004; 13.1 $\pm 0.45 \mathrm{~kg}$ ) and consequently a higher variation in the

Table 3. Changes in internal teat traits before (T0) and after (T1) milking (trial 2)

\begin{tabular}{|c|c|c|c|c|c|c|c|c|}
\hline \multirow[b]{2}{*}{ Trait } & \multirow{2}{*}{$\begin{array}{c}\text { No. of } \\
\text { measurements }\end{array}$} & \multicolumn{3}{|c|}{ T0 } & \multicolumn{3}{|c|}{$\mathrm{T} 1$} & \multirow{2}{*}{$\begin{array}{c}\text { Change } \\
(\%)\end{array}$} \\
\hline & & Mean & $\mathrm{SD}$ & $\mathrm{SE}$ & Mean & SD & $\mathrm{SE}$ & \\
\hline Teat width $(\mathrm{mm})$ & 132 & $27.2^{\mathrm{a}}$ & 2.14 & 0.19 & $25.5^{\mathrm{b}}$ & 1.93 & 0.17 & -6.07 \\
\hline Teat end width (mm) & 134 & $22.6^{\mathrm{a}}$ & 1.68 & 0.15 & $22.7^{\mathrm{a}}$ & 1.77 & 0.15 & +0.15 \\
\hline Teat cistern width (mm) & 133 & $14.0^{\mathrm{a}}$ & 3.21 & 0.28 & $7.21^{\mathrm{b}}$ & 2.87 & 0.25 & -48.5 \\
\hline Teat wall thickness, lower teat wall (mm) & 133 & $6.61^{\mathrm{a}}$ & 1.45 & 0.13 & $9.21^{\mathrm{b}}$ & 1.43 & 0.12 & +39.4 \\
\hline Teat wall thickness, upper teat wall (mm) & 133 & $6.40^{\mathrm{a}}$ & 1.51 & 0.13 & $8.99^{\mathrm{b}}$ & 1.51 & 0.13 & +40.6 \\
\hline Teat canal length (mm) & 135 & $10.6^{\mathrm{a}}$ & 1.95 & 0.17 & $12.7^{\mathrm{b}}$ & 1.90 & 0.16 & +19.0 \\
\hline Teat canal diameter (mm) & 132 & $0.99^{\mathrm{a}}$ & 0.26 & 0.02 & $1.22^{\mathrm{b}}$ & 0.25 & 0.02 & +22.6 \\
\hline Distal teat canal orifice (mm) & 133 & $2.02^{\mathrm{a}}$ & 0.69 & 0.06 & $2.61^{\mathrm{b}}$ & 0.75 & 0.07 & +28.9 \\
\hline Distal teat canal perimeter (mm) & 131 & $16.7^{\mathrm{a}}$ & 4.18 & 0.36 & $20.9^{\mathrm{b}}$ & 4.29 & 0.38 & +25.0 \\
\hline Distal teat canal surface $\left(\mathrm{mm}^{2}\right)$ & 131 & $7.04^{\mathrm{a}}$ & 2.77 & 0.24 & $10.0^{\mathrm{b}}$ & 3.28 & 0.29 & +41.5 \\
\hline
\end{tabular}

\footnotetext{
${ }_{\mathrm{a}, \mathrm{b}}$ Means within a row with different superscripts differ $(P<0.001)$.
}

${ }^{1}$ Percentage change of trait from T0 to T1. 
Table 4. Internal teat traits of multiparous $(\mathrm{n}=50)$ and primiparous $(\mathrm{n}=19)$ cows before $(\mathrm{T} 0)$ and after $(\mathrm{T} 1)$ milking (trial 2)

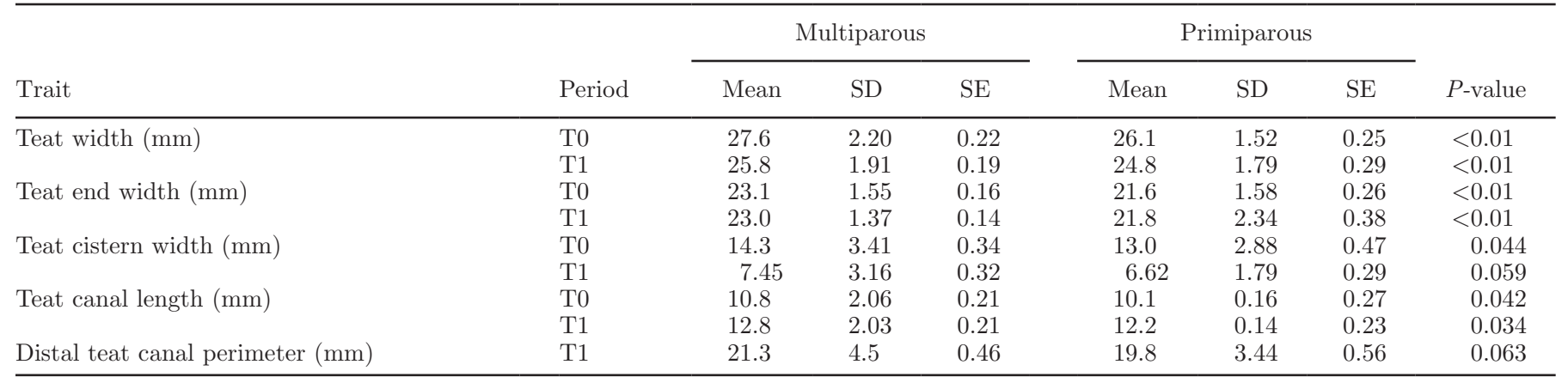

amount of teat swelling due to heavily filled cisterns. Furthermore, Weiss et al. (2004) stated that an association with milkability traits was not observed when examining externally measurable teat characteristics such as teat diameter. Therefore, ultrasonographic examination to analyze inner characteristics seems more appropriate for studying such relationships. In our experiment, cows with a peak flow rate recorded at afternoon milking $>4.0 \mathrm{~kg} / \mathrm{min}(\mathrm{n}=36)$ showed a trend for wider teat canal diameters before $(P=0.055)$ and after $(P=0.067)$ milking compared with cows with peak flow rates $<4.0 \mathrm{~kg} / \mathrm{min}(\mathrm{n}=33 ;>4.0 \mathrm{~kg} / \mathrm{min}$ : T0 $1.03 \pm 0.03 \mathrm{~mm}, \mathrm{~T} 11.25 \pm 0.27 ;<4.0 \mathrm{~kg} / \mathrm{min}: \mathrm{T} 0$ $0.94 \pm 0.02 \mathrm{~mm}, \mathrm{~T} 11.17 \pm 0.23 \mathrm{~mm})$. The threshold value reflects the average peak flow rate observed in the experimental cows during trial 2 of $4.23 \pm 1.22 \mathrm{~kg} / \mathrm{min}$ (data were normally distributed). The observed trends might be interpreted as wider TCD enabling a greater volume of milk to pass through the teat canal per unit of time. Milk yield and milk flow were both recorded at the udder level during our study. Expanding such data to the quarter level in future ultrasonographic studies will deepen our insight into the relationships between milking traits and inner teat morphology.

Parity was identified as a factor associated with changes of teat morphology during milking. Comparing multiparous $(\mathrm{n}=50)$ with primiparous $(\mathrm{n}=19)$ cows, we observed differences in various traits of inner teat morphology (Table 4). Teats of multiparous cows were wider before and after milking $(P<0.01)$ and showed larger cistern dimensions before milking $(P=0.044$ at T0) than teats of primiparous cows. These differences in teat shape might be explained by the lower average milk yield of the heifers compared with the multiparous cows (heifers: $9.47 \pm 2.17 \mathrm{~kg} / \mathrm{d}$; multiparous: $13.50 \pm$ $5.05 \mathrm{~kg} / \mathrm{d}$ ) and thus a less filled cistern and a less swollen teat. Zwertvaegher et al. (2012) reported similar findings of narrower teats in heifers using a 2-dimensional vision-based measuring technique to estimate the teat barrel diameter in an external study. Parity also affected length of the teat canal. We found longer TCL in teats of multiparous cows compared with those of heifers. Comparing Holstein cows in the first and second lactations using a $7.5-\mathrm{MHz}$ probe, Szencziová et al. (2013) also detected differences $(P<0.05)$ in length of the teat canal. Referring to the newly established traits of distal teat morphology, the perimeter of the distal teat canal (DTCp) after milking tended to be larger in multiparous than in primiparous cows; however, the level of significance was not reached in this case $(P=$ 0.063). Taking the effects of parity together, we suggest that exposure of teat tissue to mechanical milk removal increases the dimensions of inner morphological traits with advancing lactations. We thus suggest that special attention should be paid to the influence of milking machines on teat tissue with increasing age.

With regard to udder health, no major pathogens were detected in the quarter milk samples during trial $2(n=138)$. An overview of the occurrence of cultured udder pathogens is shown in Table 5. The quarters examined during trial 2 had a relatively low average SCC $\left(\log _{10} \mathrm{SCC}=4.16 \pm 0.57\right.$ cells $/ \mathrm{mL}$, or $\mathrm{SCC}=49,036$ $\pm 178,603$ cells $/ \mathrm{mL}$ ), indicating a good udder health status in the herd. In 11 out of the 138 enrolled quarters, we detected SCC $>100,000$ cells $/ \mathrm{mL}$ but without bacteriological findings and clinical symptoms. These quarters were examined for udder pathogens 2 more times with an interval of 1 wk between samplings, confirming the negative findings. Therefore, these quarters were classified as showing unspecific mastitis (DVG, 2002). Bacterial growth in the appropriate milk was the trait connected to udder health and vulnerability to mastitis in our study. We found that the newly established traits of teat morphology were especially associated with this udder health-related characteristic. We classified the scanned teats by the bacterial growth in the corresponding milk samples $(\mathrm{n}=138$; group 0 : no growth of pathogens detectable, $\mathrm{n}=100$; group 1 : growth of pathogens detectable, $\mathrm{n}=37$; contaminated samples: $\mathrm{n}=1$ ). In general, only minor pathogens were 
found during our bacteriological analyses. Samples were considered to be contaminated when 2 or more colonies of 2 or more different bacteria (without distinct excess of one type of colony) were identified. Therefore, 1 sample was excluded. The overall low bacterial growth may indicate that the determined bacteria originated from the teat canal mucosa rather than from a colonization of the whole quarter. Measured values of the newly established internal teat traits of the distal teat canal at $\mathrm{T} 0$ and $\mathrm{T} 1$ in the respective groups are shown in Table 6 . The sphincter's function is to close the teat canal's external orifice between milking times to prevent infiltration of potential mastitis-causing pathogens. Thus, a widely opened orifice after milking represents a critical risk factor for udder health. In our study, teats with bacterial growth in the appropriate milk tended to show higher values describing the teat canal external orifice (TOR) even though statistical significance was narrowly missed in this case. Consequently, texture of the teat tissue is affected by mechanical milk removal and defense mechanisms of the teat canal can be compromised by factors of the milking technique. Greater perimeter and surface values of the teat canal connote a high amount of mucosal tissue at the distal teat duct and by that represent a larger area for invading microorganisms to colonize. This may explain why we determined larger DTCp (T0: $P=0.019$; T1: $P=$ 0.003 ) and DTCs (T0: $P=0.008$; T1: $P=0.024$ ) in teats whose appropriate milk showed bacterial growth. The bacterial growth-related differences detected in the newly established traits of teat morphology, even when not including cows with udder health issues, point to the importance of the distal teat canal and its orifice for the animals' health. Integration of the 3 newly established traits in future ultrasound studies is even more intriguing because none of the common morphological traits known from the literature were demonstrated to be related to udder health in our experiments. In contrast, Klein et al. (2005) found TCL and TCD in infected quarters (SCC > 100.000 cells/ $\mathrm{mL}$ and detection of udder pathogens) to be higher ( $P$ $<0.001)$ compared with healthy quarters. Utilizing a translucent measuring ruler, Guarín and Ruegg (2016) indicated an increased risk of clinical mastitis with enlarged premilking diameter of the teat apex. These mentioned traits did not show connections to udder health in the present study, but it should be noted that no inflamed or infected quarters (SCC >100,000 cells/ $\mathrm{mL}$ and detection of udder pathogens) were enrolled. In connection with the finding of parity effect, results of an enlarged DTCp in multiparous cows after milking may be connected to an increased risk of mastitis with advancing lactation number (Breen et al., 2009). Investigating dairy cow teat canals by swab technique and highlighting a connection of teat end callosity and microbial load of the appropriate teat canal, Paduch et al. (2012) emphasized the need to identify further factors affecting the extent of microbial incidence in teat canals. During our study we could verify the dimensions of the distal teat canal (DTCp, DTCs) as being connected to the amount of bacterial growth in the respective milk sample. Therefore, these traits can be classified as a useful measurement option, and ultrasonographic investigation may be considered for

Table 5. Overview of bacteria cultured in quarter milk samples $(\mathrm{n}=138$; trial 2$)$

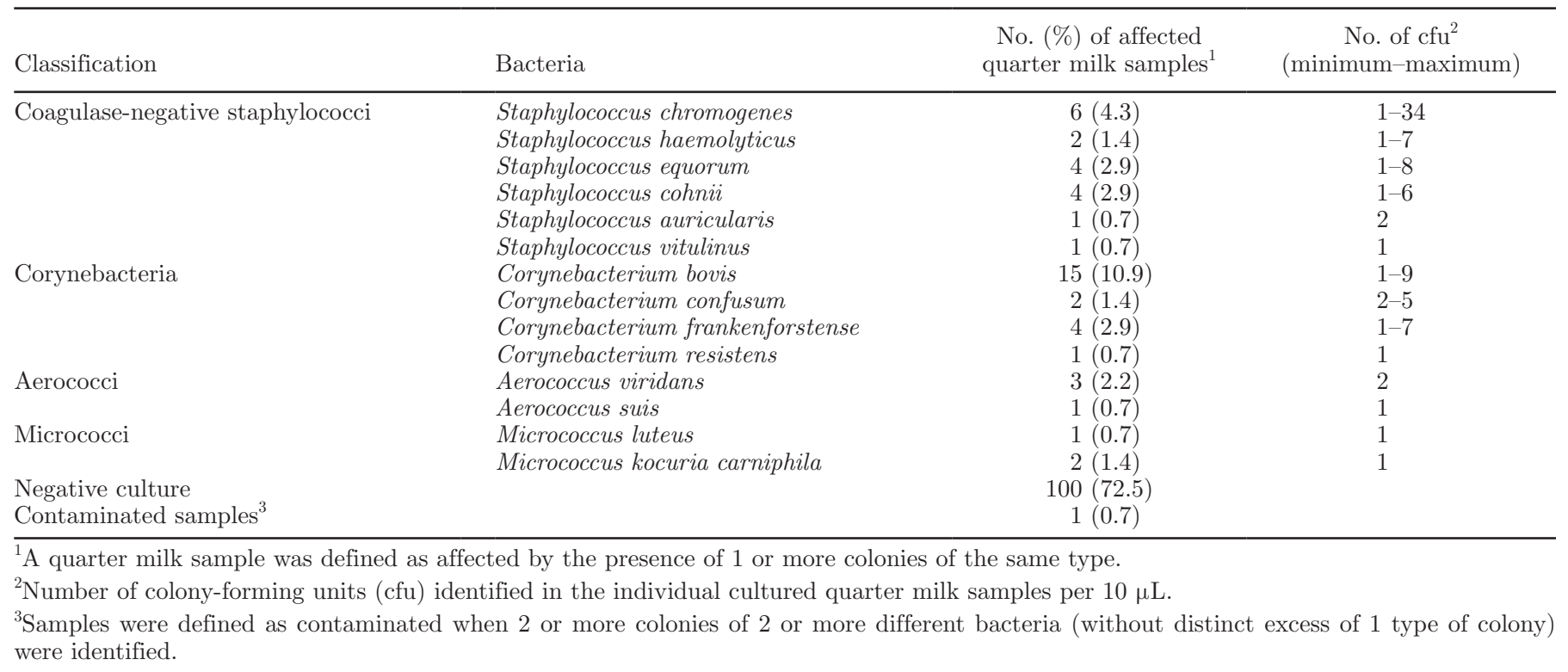




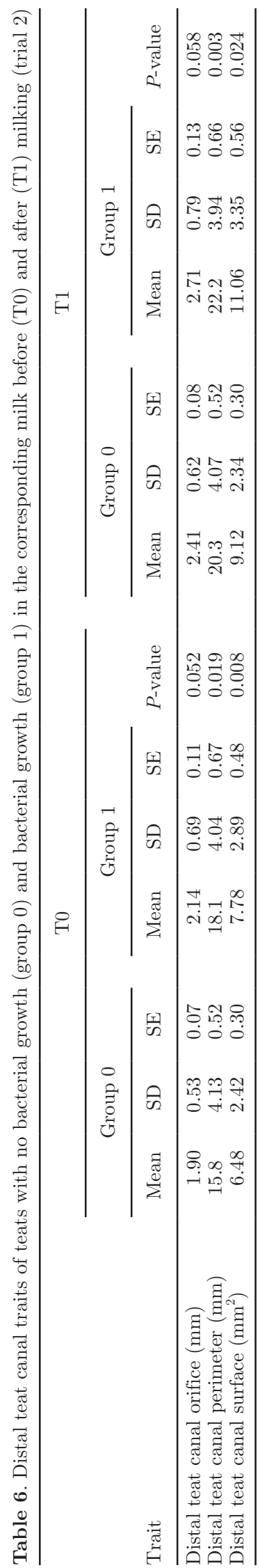

complementing common examination methods in further studies aiming to evaluate the teat canal's defense mechanisms and microbial load.

Despite all detected influencing factors, variance estimation showed that cow was the factor accounting for the largest proportion of variance in teat traits measured before milking (73\% TCL; 71\% TCW; $69 \%$ DTCp; 66\% TWT1; 58\% DTCs; 52\% TEW, TW, and TWT2; 51\% TOR; not significant for TCD) and after milking (75\% TCL; 74\% DTCp; $66 \%$ TCW; $62 \%$ DTCs; 59\% TOR; 55\% TW; 54\% TWT1; $49 \%$ TWT2; $45 \%$ TEW; not significant for TCD). These findings were in accordance with previous studies by Neijenhuis et al. (2001a) and Zwertvaegher at al. (2012). Animalspecific data (multiparous vs. primiparous, milk yield $>$ or $<11.0 \mathrm{~kg}$, peak flow rate $>$ or $<4.0 \mathrm{~kg} / \mathrm{min}$, and bacteriological findings in the corresponding milk: with or without bacterial growth) explained only marginal parts of variance during the multivariate statistics. Estimation of variance for the differences in the measured values in comparison of the time points (relative changes in teat traits from $\mathrm{T} 0$ to $\mathrm{T} 1$ ) showed that variance was partly explainable by the individual cow for only 3 out of 10 traits. This may be engendered by the fact that measured values at T0 and T1 refer to the teats' individual morphology, whereas relative changes in teat traits were caused by the external effect of the milking technique, which formed a relatively equal influencing variable for all experimental animals. Inner teat morphology differs among individual cows and quarters within cows. During our study, teat position (left front vs. right front) did account for negligible variance and was therefore left out of the model. However, it should be taken into account that the relative dimensions of teat tissue change due to the milking procedure for rear teats might be divergent, and thus both front and rear teats should be included in future studies. Rear quarters commonly contain more milk than front quarters. Removing the milking cluster in our experiments was based on a milk flow threshold value at the udder level, but the mechanical stain in front quarters might have differed from that in the hind quarters. Furthermore, observation of external teat traits in future studies may provide easy determinable additional information and thus enable investigation of associations between internal and external teat traits as performed by Weiss et al. (2004) and Ambord and Bruckmaier (2010). The present study refers to a database of high-producing, healthy Holstein cows. Investigation and comparison of the distal teat canal morphology in other breeds might be an interesting approach for further research.

Allowing for analyses of morphological changes, teat scanning has already been used for the assessment of different milking machine settings or liner types (Glee- 
son et al., 2005; Paulrud et al., 2005; Vetter at al., 2014; Besier and Bruckmaier, 2016). Application of the newly established measurement traits could also improve investigations in this case.

\section{CONCLUSIONS}

The vulnerability of the bovine teat canal to invading microorganisms cannot be measured directly by ultrasonography. However, changes in teat morphology after milking are assumed to reflect the teat canal penetrability. Therefore, the measurement of traits estimating the relative changes in teat tissue via ultrasound represents an expedient method to assess the teat condition. High-resolution ultrasonographic teat scanning served as a practicable, noninvasive tool for studying the morphological changes during milking in a repeatable way. It can therefore be applied for the evaluation of different milking techniques, liners, and milking machine settings by analyzing the reaction of the teat. Examination of the newly established traits, referring to the delicate area of the teat canal distal orifice, may result in an improved estimation of the individual teats' ability to physically defend against invading microorganisms.

\section{ACKNOWLEDGMENTS}

This research was partly conducted by members of the Center of Integrated Dairy Research (CIDRe), University of Bonn (Bonn, Germany). The authors gratefully acknowledge the assistance of the staff of the Frankenforst research station of the University of Bonn (Königswinter, Germany). Special thanks go to GEA Farm Technologies GmbH (Bönen, Germany). The project was supported by funds of the Federal Ministry of Food and Agriculture (BMEL, Bonn, Germany) based on a decision of the Parliament of the Federal Republic of Germany via the Federal Office for Agriculture and Food (BLE, Bonn, Germany) under the innovation support program.

\section{REFERENCES}

Ambord, S., and R. M. Bruckmaier. 2010. Milk flow-dependent vacuum loss in high-line milking systems: Effects on milking characteristics and teat tissue condition. J. Dairy Sci. 93:3588-3594. https://doi.org/10.3168/jds.2010-3059.

Besier, J., and R. M. Bruckmaier. 2016. Vacuum levels and milk-flowdependent vacuum drops affect machine milking performance and teat condition in dairy cows. J. Dairy Sci. 99:3096-3102. https:// doi.org/10.3168/jds.2015-10340.

Bobić, T., P. Mijić, G. Vučković, M. Gregić, M. Baban, and V. Gantner. 2014. Morphological and milkability breed differences of dairy cows. Mljekarstvo 64:71-78.

Breen, J. E., M. J. Green, and A. J. Bradley. 2009. Quarter and cow risk factors associated with the occurrence of clinical mastitis in dairy cows in the United Kingdom. J. Dairy Sci. 92:2551-2561. https://doi.org/10.3168/jds.2008-1369.

Deutsche Veterinärmedizinische Gesellschaft (DVG). 2002. Leitlinien zur Bekämpfung der Mastitis des Rindes als Bestandsproblem. Fachgruppe: Milchhygiene; Sachverständigenausschuss: Subklinische Mastitis. Verlag Deutsche veterinärmedizinische Gesellschaft, Gießen, Germany.

Deutsche Veterinärmedizinische Gesellschaft (DVG). 2009. Leitlinien zur Entnahme von Milchproben unter antiseptischen Bedingungen und Isolierung und Identifizierung von Mastitiserregern. Fachgruppe: Milchhygiene; Sachverständigenausschuss: Subklinische Mastitis. Verlag Deutsche veterinärmedizinische Gesellschaft, Gießen, Germany.

Fasulkov, I., N. Vasilev, M. Karadaev, and G. Dineva. 2014. Vizualisation and measurement of teat structures in black-and-white cows through ultrasonography. Maced. Vet. Rev. 37:89-93.

Gleeson, D. E., E. J. O'Callaghan, W. J. Meaney, and M. V. Rath. 2005. Effect of two milking systems on the milking characteristics, teat tissue changes and new infection rate of dairy cows. Anim. Res. 54:259-267. https://doi.org/10.1051/animres:2005025.

Gleeson, D. E., E. J. O'Callaghan, and M. V. Rath. 2004. Effect of liner design, pulsator settings, and vacuum level on bovine teat tissue changes and milking characteristics as measured by ultrasonography. Ir. Vet. J. 57:289-296.

Guarín, J. F., and P. L. Ruegg. 2016. Short communication: Pre- and postmilking anatomical characteristics of teats and their associations with risk of clinical mastitis in dairy cows. J. Dairy Sci 99:8323-8329. https://doi.org/10.3168/jds.2015-10093.

Hamann, J., G. A. Mein, and S. Wetzel. 1993. Teat tissue reactions to milking: Effects of vacuum level. J. Dairy Sci. 76:1040-1046. https://doi.org/10.3168/jds.S0022-0302(93)77432-9.

Hillerton, J. E., I. Ohnstad, J. R. Baines, and K. A. Leach. 2000 Changes in cow teat tissue created by two types of milking cluster. J. Dairy Res. 67:309-317.

IDF. 1987. Machine milking and mastitis. Bulletin no. 215. International Dairy Federation, Brussels, Belgium.

Klein, D., M. Flöck, J. K. Khol, S. Franz, H. P. Stüger, and W. Baumgartner. 2005. Ultrasonographic measurement of the bovine teat: Breed differences, and the significance of measurements for udder health. J. Dairy Res. 72:296-302. https://doi.org/10.1017/ S0022029905000920.

Krömker, V. 2014. Zur Bedeutung des Zitzenkanals in der Ätiologie und Prophylaxe der Mastitis beim Rind. Habilitation Thesis. University of Veterinary Medicine, Hannover, Germany.

Kuchler, K. 2011. Der Einfluss des Melkens auf Durchblutung und Morphologie der Rinderzitze untersucht mittels Color Angiographie und B-Mode Sonographie. PhD Thesis. Ludwig-Maximilian University, Munich, Germany

Neijenhuis, F., G. H. Klungel, and H. Hogeveen. 2001a. Recovery of cow teats after milking as determined by ultrasonographic scanning. J. Dairy Sci. 84:2599-2606. https://doi.org/10.3168/jds S0022-0302(01)74714-5.

Neijenhuis, F., G. A. Mein, J. S. Britt, D. J. Reinemann, J. E. Hillerton, R. Farnsworth, J. R. Baines, T. Hemling, I. Ohnstad, N. Cook, W. F. Morgan, and L. Timms. 2001b. Evaluation of bovine teat condition in commercial dairy herds: 4. Relationship between teat end callosity or hyperkeratosis and mastitis. Pages 362-366 in Proc. 2nd Int. Symp. Mastitis and Milk Quality, Vancouver, BC, Canada. National Mastitis Council, Madison, WI.

O'Shea, J. 1987. Machine milking and mastitis. Section 2: Machine milking factors affecting mastitis. A literature review. Bull. Int. Dairy Fed. 215:5-32.

Paduch, J. H., E. Mohr, and V. Krömker. 2012. The association between teat end hyperkeratosis and teat canal microbial load in lactating dairy cattle. Vet. Microbiol. 158:353-359.

Paulrud, C. O. 2005. Basic concepts of the bovine teat canal. Vet. Res. Commun. 29:215-245.

Paulrud, C. O., S. Clausen, P. E. Andersen, and M. D. Rasmussen. 2005. Infrared thermography and ultrasonography to indirectly monitor the influence of liner type and overmilking on teat tissue recovery. Acta Vet. Scand. 46:137-147. 
Penry, J. F., J. Upton, G. A. Mein, M. D. Rasmussen, I. Ohnstad, P. D. Thompson, and D. J. Reinemann. 2017. Estimating teat canal cross-sectional area to determine the effects of teat-end and mouthpiece chamber vacuum on teat congestion. J. Dairy Sci. 100:821-827. https://doi.org/10.3168/jds.2016-11533.

Strapák, P., E. Strapáková, M. Rušinová, and I. Szencziová. 2017. The influence of milking on the teat canal of dairy cows determined by ultrasonographic measurements. Czech J. Anim. Sci. 62:75-81. https://doi.org/10.17221/68/2015-CJAS.

Szencziová, I., P. Strapák, L. Stádník, J. Ducháček, and J. Beran. 2013. Relationship of udder and teat morphology to milking characteristics and udder health determined by ultrasonographic examinations in dairy cows. Ann. Anim. Sci. 4:783-795. https://doi .org/10.2478/aoas-2013-0053.

Vetter, A., H. A. van Dorland, M. Youssef, and R. M. Bruckmaier. 2014. Effects of a latency period between pre-stimulation and teat cup attachment and periodic vacuum reduction on milking characteristics and teat condition in dairy cows. J. Dairy Res. 81:107112. https://doi.org/10.1017/S0022029913000617.
Weiss, D., M. Weinfurtner, and R. M. Bruckmaier. 2004. Teat anatomy and its relationship with quarter and udder milk flow characteristics in dairy cows. J. Dairy Sci. 87:3280-3289. https://doi.org/ 10.3168/jds.S0022-0302(04)73464-5.

Wieland, M., J. M. Melvin, P. D. Virkler, D. V. Nydam, and W. Heuwieser. 2018. Technical note: Development and evaluation of a standard operating procedure for ultrasound-based measurements of teat canal dimensions in dairy cows. J. Dairy Sci. 101:1518-1523.

Zwertvaegher, I., S. De Vliegher, B. Verbist, A. Van Nuffel, J. Baert, and S. Van Weyenberg. 2013. Short communication: Associations between teat dimensions and milking-induced changes in teat dimensions and quarter milk somatic cell counts in dairy cows. J. Dairy Sci. 96:1075-1080. https://doi.org/10.3168/jds.2012-5636.

Zwertvaegher, I., S. Van Weyenberg, S. Piepers, J. Baert, and S. De Vliegher. 2012. Variance components of teat dimensions in dairy cows and associated factors. J. Dairy Sci. 95:4978-4988. https:// doi.org/10.3168/jds.2011-5296. 